\title{
Early cellular changes are indicators of pre-bleaching thermal stress in the coral host
}

\author{
T.D. Ainsworth ${ }^{\mathrm{a}, *}$, O. Hoegh-Guldberg ${ }^{\mathrm{a}}$, S.F. Heron ${ }^{\mathrm{b}}$, W.J. Skirving ${ }^{\mathrm{b}}$, W. Leggat ${ }^{\mathrm{a}, \mathrm{c}}$ \\ a Centre for Marine Studies and The ARC Centre of Excellence for Coral Reefs Studies, The University of Queensland, St. Lucia, QLD, 4072 Australia \\ ${ }^{\mathrm{b}}$ NOAA NESDIS Coral Reef Watch 1335 East-West Highway, SSMC1, Silver Spring MD 20910, USA \\ c School of Pharmacy and Molecular Sciences and the Comparative Genomics Centre, James Cook University, Townsville, Qld, 4811, Australia
}

\section{A R T I C L E I N F O}

\section{Article history:}

Received 13 December 2007

Received in revised form 15 May 2008

Accepted 19 June 2008

\section{Keywords:}

Coral bleaching

Cell biology

Stress response

\begin{abstract}
A B S T R A C T
Thermal stress causes the coral-dinoflagellate symbiosis to disassociate and the coral tissues to whiten. The onset and occurrence of this coral bleaching is primarily defined via the dinoflagellate responses. Here we demonstrate that thermal stress responses occur in the coral host tissues in the days before the onset of coral bleaching. The observed sequence of thermal responses includes reductions in thickness of coral tissue layers and apoptosis of the cells prior to reductions in symbiont density. In the days before the onset of coral bleaching the outer coral tissue layer (epithelium) thickness reduces and apoptosis occurs within the gastrodermis. Two days following this, coinciding with an initial reduction of symbiont density (by approximately 25\%), gastrodermal thickness decreased and apoptosis of host cells was identified in the epithelium. This was eventually followed by large reduction in symbiont density (by approximately 50\%) consistent with coral bleaching. Both pro-apoptotic and anti-apoptotic genes are identified in the reef building coral Acropora aspera, demonstrating the necessary pathways are present for fine control of host apoptosis. Our study shows that defining periods of host stress based on the responses defined by dinoflagellate symbiont underestimates the importance of early cellular events and the cellular complexity of coral host.
\end{abstract}

(c) 2008 Elsevier B.V. All rights reserved.

\section{Introduction}

Mass bleaching of corals has been reported to be increasing in recent years and is directly correlated with increasing sea temperatures driven by global climate change (Hoegh-Guldberg, 1999). Bleaching is now considered one of the major threats to the sustainability of reefs worldwide (Hoegh-Guldberg, 1999; Hughes et al., 2003). Coral bleaching is broadly defined as the loss or reduction of endosymbiotic dinoflagellates or their associated pigments from the coral host cells; with severe or sustained bleaching resulting in mortality of the coral colony (Coles and Jokiel, 1977; Hoegh-Guldberg and Smith, 1989; Kleppel et al., 1989; Porter et al., 1989; Lesser, 1996; Szmant and Gassman, 1990; Glynn and D'Croz, 1990). This observable bleaching pattern in reef corals is a generalised response to stress and occurs as a reaction to many environment factors including high (Hoegh-Guldberg and Smith, 1989; Glynn, 1991; Glynn and D'Croz, 1990) and low water temperature (Hoegh-Guldberg and Fine, 2004), high light or UV (Lesser et al., 1990), aerial exposure (Leggat et al., 2006), cyanide (Jones and Hoegh-Guldberg, 1999), low salinity (Kerswell and Jones, 2003) and herbicides (Jones, 2005).

Increased seawater temperatures directly affect the photosynthetic apparatus of Symbiodinium, leading to an increase in production of reactive oxygen species and the disassociation of the coral-Symbiodinium

\footnotetext{
* Corresponding author.

E-mail address: tracy.ainsworth@jcu.edu.au (T.D. Ainsworth).
}

endosymbiosis through a variety of possible cellular mechanisms (Gates et al., 1992). Proposed cellular mechanisms underlying coral bleaching include active host processes such as exocytosis and host cell apoptosis, and passive processes such as necrosis (Gates et al., 1992) (for reviews of apoptosis see Elmore, 2007 and apoptotic pathways of lower invertebrates see Zmasek et al., 2007). Despite intense study over the last 10 years, the exact point of thermal damage in Symbiodinium has not been comprehensively demonstrated. A variety of evidence has been presented supporting direct temperature effects on the photosystem II (PSII) (Iglesias-Prieto, 1997), in particular the protein D1 (Warner et al., 1999; Lesser and Farrell, 2004), the repair mechanism of PSII (Takahashi et al., 2004); the synthesis of accessory pigments (Takahashi et al., 2008),; the dark reactions of photosynthesis (Jones et al., 1998); degradation of Symbiodinium thylakoid membranes (Tchernov et al., 2004) and possibly a reduction of Rubisco activity (Leggat et al., 2004), all of which lead to a production of reactive oxygen species. All of these hypotheses are consistent with the observation that the onset of coral bleaching is often characterised by a reduction in the dark adapted photosynthetic yield of PSII associated with the reduction of endosymbiont density (Jones et al., 1998; Jones et al., 2000; Warner et al., 1999). This measurable reduction of photosynthetic yield and the ability to easily monitor photosystem II efficiency using fluorescence (Jones et al., 1999) has driven the pre-occupation of recent studies with the condition of the dinoflagellate symbiont during heat stress (Fitt et al., 2001). One consequence of this preoccupation has been a limited number of experimental studies that have examined the underlying cellular mechanisms occurring specifically within the coral animal host during 
the initial stages of thermal stress and subsequent bleaching (Edmunds and Gates, 2003; Lesser and Farrell, 2004; Dove et al., 2006). This is despite the proposal that a number of host mechanisms that may be involved in coral stress and bleaching (Gates et al., 1992).

The increasing incidence of disease prevalence among marine and terrestrial animals has been linked to climate change (Harvell et al., 2002; Sutherland et al., 2004; Bruno et al., 2007). Recent studies have proposed that this linkage is related to primary pathogens having an increased virulence during periods of increased sea temperatures (Bruno et al., 2007; Rosenberg et al., 2007). An alternative viewpoint suggests that primary environmental stressors such as extreme temperatures and thermal stress in summer months directly affect coral animal without the involvement of a primary pathogen (Lesser et al., 2007; Leggat et al., 2007b). Understanding the role of 'abiotic' disease in cases of coral disease has received little attention. Abiotic diseases and their impacts are being increasingly recognised in other systems (e.g. higher plants Ayres and Lombardero, 2000; Garrett et al., 2006; Boland et al., 2004) as an important threat related to climate change. In a review of abiotic disease and stress in plants, Ayres (1984) proposes a model for the integration of stress and various levels of sub-cellular, cellular and organism responses in governing disease outcomes and breakpoint (or point of irreversible change or damage) related to increasing stress impacts. An understanding of the links between stress and disease in coral reef systems has been hindered by a lack of understanding of coral cell biology and coral stress biology. In determining the role of stress, abiotic impacts, and increasing disease on coral reefs worldwide we require a greater understanding of the subcellular and cellular changes that occur not only during the onset of bleaching but also from the initial stress response and through the communication of stress across the holobiont.

In the present study, we explore the cellular and tissue changes that occur in the coral host during the early stages of thermal stress. In doing this, we describe a scenario where the host cellular biology is affected by early thermal stress prior to the bleaching response being observed in the Symbiodinium.

\section{Materials and Methods}

\subsection{Experimental design}

Acropora aspera colonies ( 3 large distinct patch colonies) on the reef flat of Heron Island $\left(23.44^{\circ} \mathrm{S}, 151.91^{\circ} \mathrm{E}\right)$ were selected as the experimental organism and a total of 108 branches of at least $7 \mathrm{~cm}$ in length were collected and transported immediately to holding tanks in a flow-through seawater system. The coral branches were randomly assigned to one of 4 experimental $60 \mathrm{l}$ plastic aquaria with flow rates of approximately $10 \mathrm{Imin}^{-1}$, and stored in polypropylene racks at least $10 \mathrm{~cm}$ above the base of the tank to ensure mixing and flow of seawater around the entire branches. Two of the four aquaria were used as heat treatment tanks, and two as control tanks. Control and treatment tanks were fed from separate 10001 sumps; this design was chosen to allow for effective heating of water in the experimental tanks. The tanks were maintained for 4 days prior to coral collection to allow the microbial surface layers to stabilise. After collection of the coral colonies, the system was left at ambient flow through conditions for 5 days to acclimate before initiation of the experiment. The control tanks remained at ambient sea surface temperatures throughout the experiment, while heat treatments involved a daily $1{ }^{\circ} \mathrm{C}$ increase in water temperature at 0800 hours on each experimental day throughout the experimental period (Fig. 1). Temperatures increased above the control $28{ }^{\circ} \mathrm{C}$ in experimental tanks on the 9th of December to $29{ }^{\circ} \mathrm{C}$ (Day 3), the 10th of December to $30{ }^{\circ} \mathrm{C}$ (day 4), the 11th of December to $31{ }^{\circ} \mathrm{C}$ (day 5), and over the bleaching threshold of $32{ }^{\circ} \mathrm{C}$ on the 12th (day 6) continuing until the 15th of December (Day 9). To replicate natural reef conditions, normal temperature fluctuations over the 24 hour day/night periods were maintained (Fig. 1). Temperature in each of the four tanks was monitored using Odyssey data loggers (Christchurch, New Zealand) every two minutes through the experimental and acclimation periods.

Two entire branches were arbitrarily sampled from each tank each day, from one day before the experimental period and daily throughout the experimental period for tissue processing. Five branches in each experimental aquaria were assigned solely for measurement of dark adapted Fv/Fm using an Imaging-PAM Fluorometer (Walz, Germany) to avoid handling effects on tissues and cell responses. These five branches were used to record the onset of coral bleaching as measured by a sustainable downturn in photosynthetic yield (Jones et al., 1998). Branches were also sampled from $A$. aspera coral colonies during a natural bleaching event in the field during December 2005 and January 2006. The branches were collected at midday on the low tide and were transported, immediately fixed, handled, processes and measured as per the experimental coral samples.

\subsection{Sample preservation and tissue processing}

Coral braches were randomly selected and sampled at precisely mid-day, daily, from both experimental and control aquaria. Branches were fixed individually in $50 \mathrm{ml}$ of $4 \%(\mathrm{w} / \mathrm{v})$ paraformaldehyde in sterile phosphate buffered saline (PBS, pH 7.4) (Ainsworth et al., 2006; Ainsworth et al., 2007) for $12 \mathrm{~h}$ at $4{ }^{\circ} \mathrm{C}$, and then stored in PBS at $4{ }^{\circ} \mathrm{C}$. Prior to decalcification with $20 \%(\mathrm{w} / \mathrm{v}$ ) EDTA ( $\mathrm{pH} 8$ ), the coral branches were dissected into 3 regions lengthwise, to allow cross-sectioning of

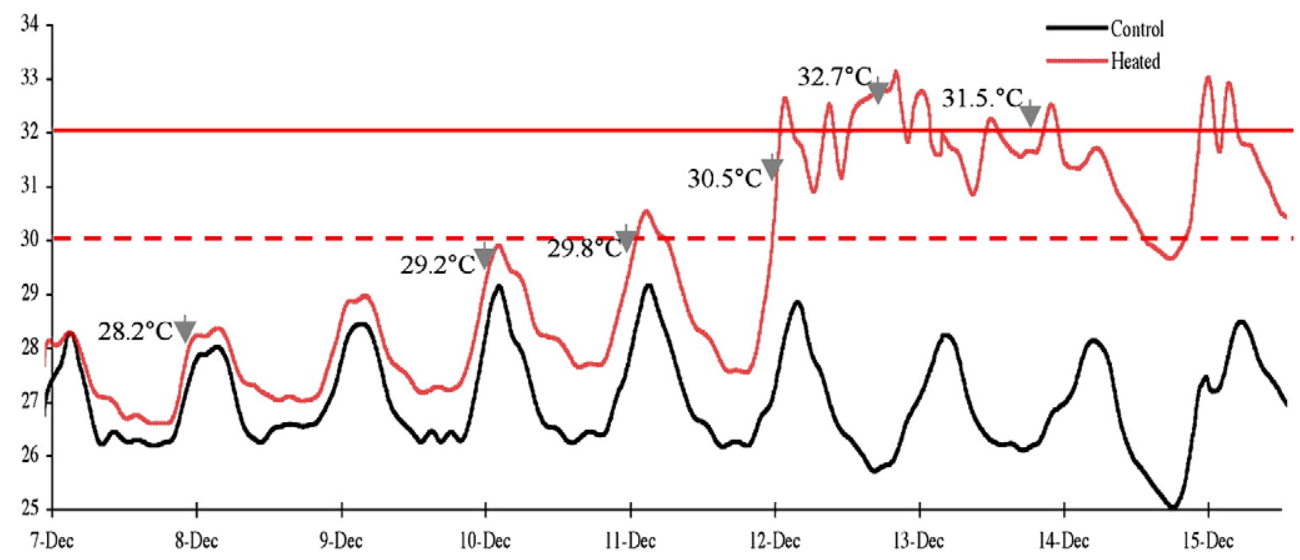

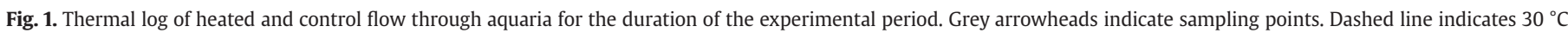
thermal impact, solid line indicates $32{ }^{\circ} \mathrm{C}$ thermal threshold. 
the coral braches and measurements of the coral tissue layers to be taken from all regions along the length of the coral branch (base, centre and tip) to account for variability within the coral branch. Decalcified coral samples were then processed for standard paraffin embedding, this included washes of $70 \%, 80 \%$, two of $95 \%$ and three of $100 \%$ ethanol for 40 min each, three xylene washes for 40 min and then 3 paraffin washes under vacuum for $40 \mathrm{~min}$ each prior to embedding in paraffin. Serial tissue sections $(4 \mu \mathrm{m})$ were taken from samples each day of the experimental period and prior to experimental manipulation, and were collected onto Superfrost Plus slides (Menzel, Brauschweig, Germany). The tissue sections were then stained using Harris's haematoxylin and eosin (with Phyloxine B) (Sigma-Aldrich Pty Ldt, \# HHS32 and HT110-1-32).

\subsection{Tissue structure and physiology}

Measurements of the thickness of coral tissue layers were conducted on an Olympus BX4 microscope at 100 times magnification. Tissue regions between polyps comprising the coenosarc were selected for measurement due to the consistency and evenness of the tissues. Two tissue sections, separated by at least $150 \mu \mathrm{m}$ from each of the three branch regions (tip, centre and base) were investigated; from each tissue section, 9 measurements were made of the epithelial and gastrodermal tissues, resulting in 54 measurements taken from each coral on each experimental day, which were averaged for each region, with two samples taken per aquarium per day, 216 measurements of each parameter were taken each day from both treated and control coral branches. The population density of Symbiodinium $s p$. was determined via cell counts within each of the tissue sections. The density of endosymbiotic algae within each tissue section is normalised to the total area of the coral tissue (symbionts per $\mathrm{cm}^{2}$ of coral tissue) as opposed to the traditional measure of symbiont density as per $\mathrm{cm}^{2}$ of coral skeleton.

\subsection{Histopathology}

The extent of mass tissue necrosis (swelling and lysis of cells, disruption of cell structure) was determined via visual assessment using light microscopy of H\&E stained tissue sections. In situ labelling of $3^{\prime}$ end of DNA fragments was used to investigate the presence and extent of programmed cell death (Ainsworth et al., 2007; Ainsworth et al., 2006) using the ApopTag in situ apoptosis detection kit as per manufacturers recommendations (S7101, Chemicon International, Inc. USA). This has been shown to distinguish apoptosis from necrosis by specifically detecting DNA cleavage and chromatin condensation associated with apoptosis and confirmed by the lack of necrotic morphology. Cells were defined as apoptotic if the nuclear area of the cell was positively labelled as indicated by red stain as opposed to the blue haematoxylin counterstained non-apoptotic nuclei (Ainsworth et al., 2007).

\subsection{Statistical analysis}

All parameters were analysed using a nested ANOVA design using Statistic V7 (Statsoft Oklahoma, USA). Post-hoc analysis was performed with a Tukey's post hoc test.

\subsubsection{PAM flourometry}

An imaging Pulsed Amplitude Modulated (iPAM) fluorometer (imaging-PAM, Waltz Gmbh, Germany) was used to examine the photosynthetic efficiency of the algal endosymbionts. At $1800 \mathrm{~h}$ each day coral branches were dark adapted for $30 \mathrm{~min}$ and the dark adapted quantum yield of photosystem II determined using the Genty equation $\mathrm{Y}=\left(\mathrm{F}_{\mathrm{m}}-\mathrm{F}_{\mathrm{o}}\right) / \mathrm{Fm}$ (Genty et al., 1989).

\subsubsection{Apoptotic gene detection, sequencing and phylogenetic analysis}

In order to support the assumption that apoptotic cellular processes occur in Acroporid corals, apoptotic pathway genes were identified in A. aspera. An Expressed Sequence Tag (EST), which was later confirmed as originating from the coral host, was identified as Bcl-2 like from an existing EST sequence library (Leggat et al., 2007a), derived from the Symbiodinium isolated from this coral. This library was known to contain approximately $10 \%$ coral host contamination (Leggat et al., 2007a). Subsequently primers were designed for this sequence and used to amplify the full length transcript from the cDNA library. In addition, the corresponding sequence was obtained from a library constructed from the coral holobiont Acropora millepora. Total RNA was isolated from A. millepora by grinding an entire branch under liquid nitrogen, RNA was then purified using the RNAspin kit (GE Healthcare, Uppsala Sweden). mRNA was subsequently purified using the Poly(A)Purist kit (Ambion, Texas, USA) and a directional phage library was constructed in $\lambda$-ZAP II (Stratagene, La Jolla, California, USA) as per the manufacturer's instructions, this library was used as a template to amplify the complete cDNA sequences using vector and gene specific primers (Leggat et al., 2007a). Searches of the NCBI database revealed a partial Bax-like sequence (accession number DY581529) from A. millepora, this was used to design primers and amplify the complete cDNA sequence from both the $A$. aspera and A. millepora holobiont libraries. The cDNA sequence for both the Bcl-2like and Bax-like proteins were identical for both $A$. aspera and A. millepora. The origin of these genes (coral vs Symbiodinium) was confirmed by amplifying a 450 bp genomic DNA fragment from $A$. millepora sperm, which is Symbiodinium free, and genomic DNA isolated from long-term Symbiodinium cultures. Products were only amplified from the coral genomic DNA, when this product was sequenced it exactly matched the obtained cDNA sequence. Phylogenetic analyses were conducted using the program Clustal W (Thompson et al., 1994) from BioManager by ANGIS (http://www. angis.org.au), alignments were bootstrapped 1000 times and the trees constructed using maximum likelihood (Felsenstein, 1989) with Tree Puzzle (Version 5.2).

\subsubsection{Satellite tracking of localised thermal anomalies}

Weekly averages of sea-surface temperature (SST) were constructed for the Great Barrier Reef using only high quality-control values (Pathfinder Version 5.0 dataset, NOAA 2007, http://www. nodc.noaa.gov $/ \mathrm{sog} /$ pathfinder $4 \mathrm{~km} /$ ). This provides daily global SST data at approximately 4-km resolution (Global Area Coverage) for the period during 1985-2006. Missing data pixels and data gaps were temporally and spatially filled using standard techniques of climatology-comparisons. The resulting dataset comprises 52 one-week periods for each year, where the weekly-mean (WM) temperature is the average of each week's SST values throughout 1985-2006. The NOAA Coral Reef Watch maximum monthly means (MMM) climatology covers the globe at 0.5 -degree $(50-\mathrm{km})$ resolution http:// coralreefwatch.noaa.gov.

\section{Results}

\subsection{Experimental bleaching}

Dark-adapted photosynthetic yield was significantly different between treatments $\left(F_{1,128}=347.96, p<0.00005\right)$ with a significant treatment $\times$ day effect $\left(F_{14,128}=185.10, p<0.00005\right)$ while there was no significant tank effect. Post-hoc analysis found significant differences between control and heated coral photosynthetic yields on days 7 and 8 (Fig. 2b). Symbiodinium cell densities were also significantly different between treatments and controls with post hoc analysis showing significant differences between population densities on day 7 and 8 (Fig. 2a). These decreases in dark-adapted yield and cell density occurred when temperatures exceeded $32{ }^{\circ} \mathrm{C}$ for $24 \mathrm{~h}$ (Figs. 1 and $2 \mathrm{a}, \mathrm{b}$ ). An identical thermal threshold $\left(32^{\circ} \mathrm{C}\right)$ was identified in previous studies on the same species at Heron Island (Dove, 2004). As temperatures of $32{ }^{\circ} \mathrm{C}$ and above continued, PSII yield and Symbiodinium cell densities 

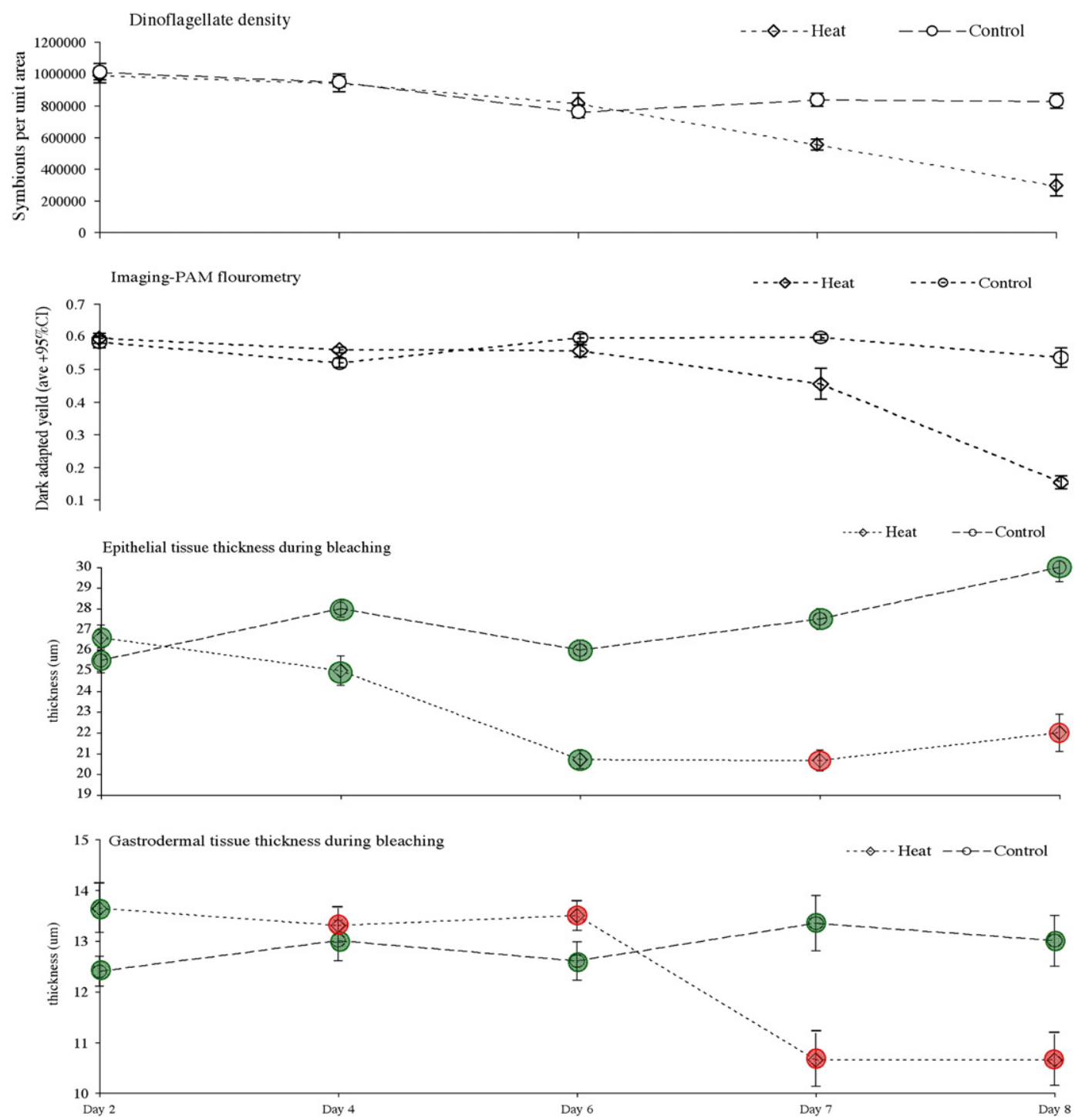

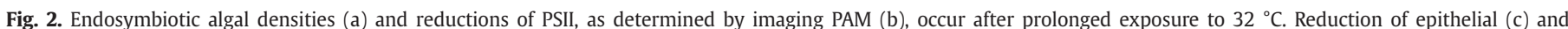

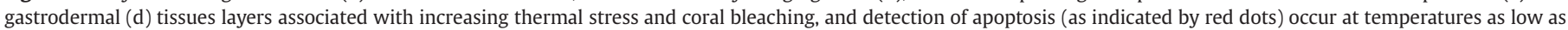

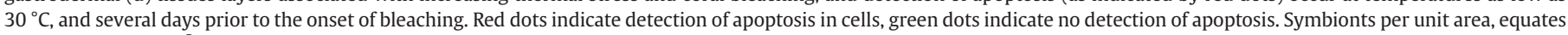
to symbionts per $\mathrm{cm}^{2}$ of coral tissue. Where no stated error bars represent the standard error.

continued to decline until conditions of severe bleaching were reached (PSII yield $<0.3$, cell density reduction $>50 \%$ ).

Coral branches were sampled for histological analysis throughout the experimental period. Significant changes in the tissue pathology of A. aspera were detectable long before any reductions in the population densities or dark-adapted photosynthetic yields of Symbiodinium were observed. The thickness of the coral epithelial layer was significantly smaller in heated corals than in controls $\left(\mathrm{F}_{1,20}=47.694\right.$, $p<0.00005)$ with a significant treatment by day effect $\left(\mathrm{F}_{8,20}=6.5616\right.$, $p=0.00031$ ). Post hoc analysis showed that the treatment thickness was significant smaller after exposure to $29^{\circ} \mathrm{C}$ (day 4) with a reduction of approximately $30 \%$ after exposure to $31{ }^{\circ} \mathrm{C}$ (day 6) (Fig. 2c). In contrast, significant reductions in the coral gastrodermal layer did not occur until the reduction of photosynthetic yield and loss of the endosymbiotic algae on experimental days 7 and 8 (Fig. 2d).

Apoptotic cell death was detectable in tissue layers of $A$. aspera following exposure to $30{ }^{\circ} \mathrm{C}$ (Fig. 2). This was first found only in the gastrodermal cell layers (Fig. 2d) and was limited primarily to small regions associated with the mesenterial tissues (Fig. 3). It was also more pronounced following exposure to $32{ }^{\circ} \mathrm{C}$ (Figs. 2 and 3).
Apoptotic cell death was evident within all tissue layers after the first period of $32{ }^{\circ} \mathrm{C}$ occurring on experimental day 7 at which point initial bleaching effects could be observed in the endosymbiont (Fig. 2c, d). Evidence for mass necrotic cell death or a loss of tissue integrity occurred following the reduction of endosymbiotic algal density on experimental day 8 (Fig. 4), as would be expected with the severe bleaching observed. The corals remaining within the experimental conditions following day 8 showed no signs of photosynthetic activity or tissue integrity and macro-algal overgrowth was observed to occur rapidly.

\subsection{Characterisation of $\mathrm{Bcl}-2$ like and Bax-like genes}

Apoptosis is controlled by a variety of regulatory proteins of the Bcl-2 family, which includes anti-apoptotic Bcl-2-like proteins and pro-apoptotic Bax-like proteins. In higher organisms, the expression of these "life and death proteins" governs apoptosis of the cells (Spierings et al., 2005; Lanave et al., 2004). To take the first steps to understand the capability of corals to express Bcl-2-like and Bax-like proteins, existing cDNA libraries were screened to detect the 


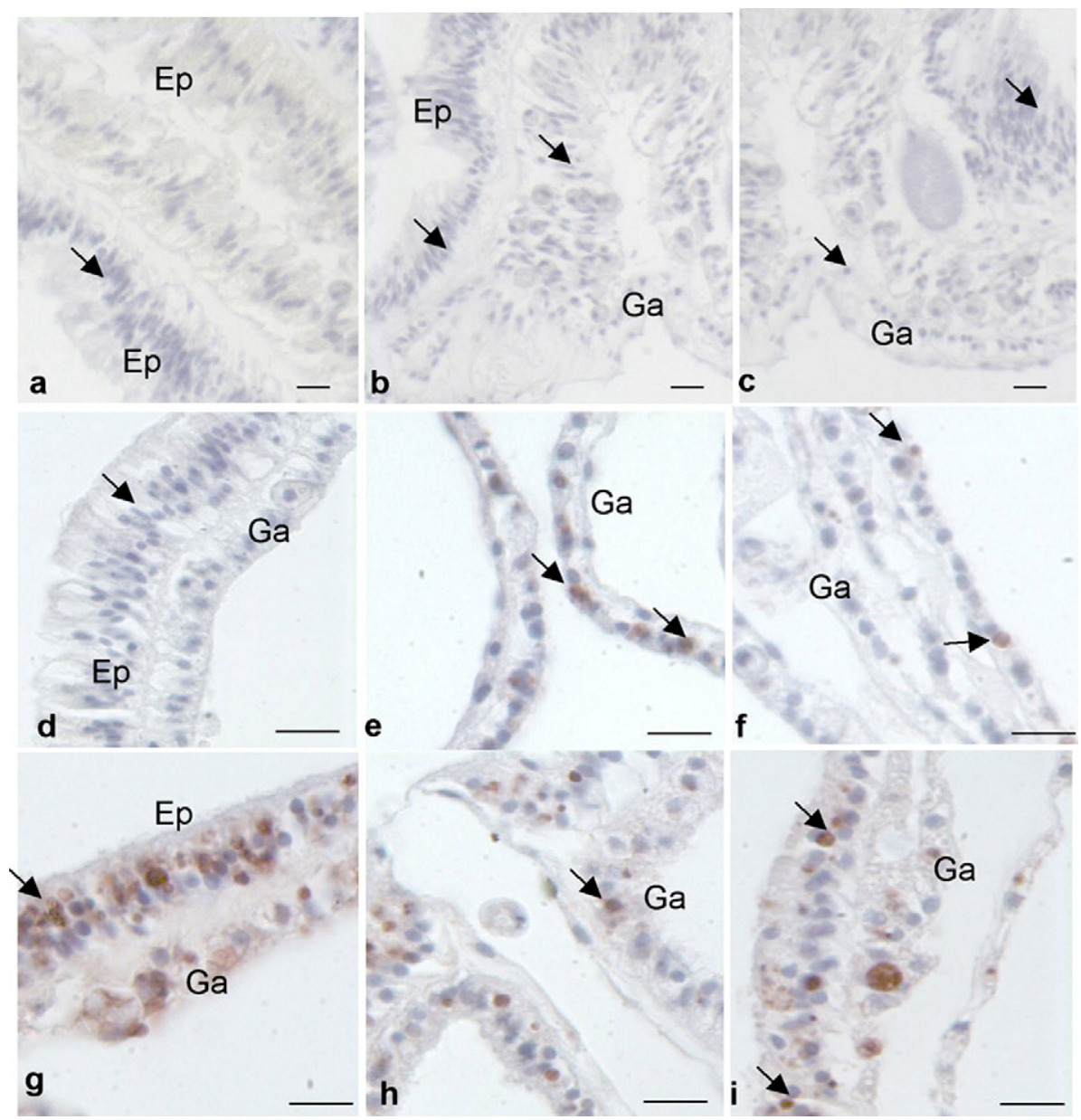

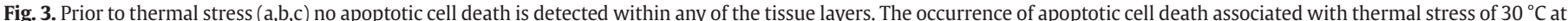

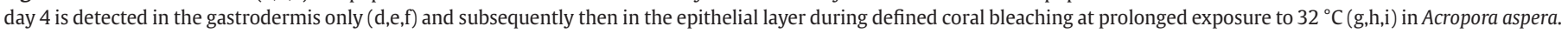
Arrowheads indicate nuclear stain. Apoptotic nuclei red, counterstain nuclei blue. Scale bar, $20 \mu \mathrm{m}$, Ep, epithelium, Ga, Gastroderm.

presence of Bcl-2-like and Bax-like genes. Transcripts encoding for both a Bcl-2-like (EU161957) and Bax-like (EU161958) protein were found (Fig. 5a), indicating that pathways similar to those in other organisms operate within Acroporid corals of the GBR. Exploration of the sequence information revealed that both transcripts contained putative $\mathrm{BH} 1, \mathrm{BH} 2$, and $\mathrm{BH} 3$ domains (Fig. 5a), while the Bcl-2 like transcript also contained a putative BH4 domain, which is characteristic of the anti-apoptotic members of this protein family. Phylogenetic comparison of the BH3 domain of coral Bcl-2 and Bax homologs cluster with the anemone (Aipatsia sp.) (Dunn et al., 2006) homolog and representative of both vertebrate and invertebrate proteins found that the coral and anemone sequences form a distinct cluster
(Fig. 5b). Within the Cnidarian cluster the Aiptasia sp. and coral proapoptotic genes were found on the same branch with high bootstrap support (Fig. 5b). The BH3 domain has previously been identified as a suitable region for phylogenetic analysis of the Bcl-2 family of proteins (Lanave et al., 2004).

\subsection{Host changes during field bleaching at Heron Island}

Almost coincidental with the experimental bleaching of Acropora aspera a thermal anomaly (20th Dec 2004 - 4th Jan 2005) resulted in bleaching on the reef flat of Heron Island ( $\left.151^{\circ} 54^{\prime} 40^{\prime \prime} \mathrm{E}, 23^{\circ} 46^{\prime} 22^{\prime \prime} \mathrm{S}\right)$. The progression of weekly-averaged sea-surface temperature (SST)
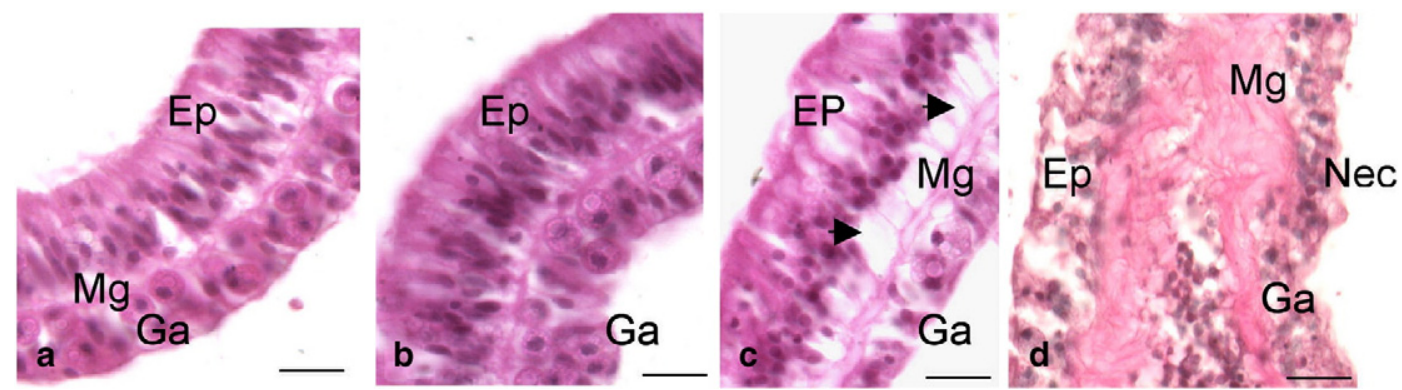

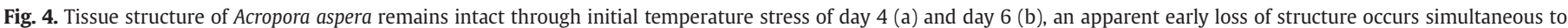
bleaching and symbiont loss (Day 7) (c), the onset of necrotic cell death occurs after the gross impact of bleaching and endosymbiont loss (day 8 ) (d). 
a

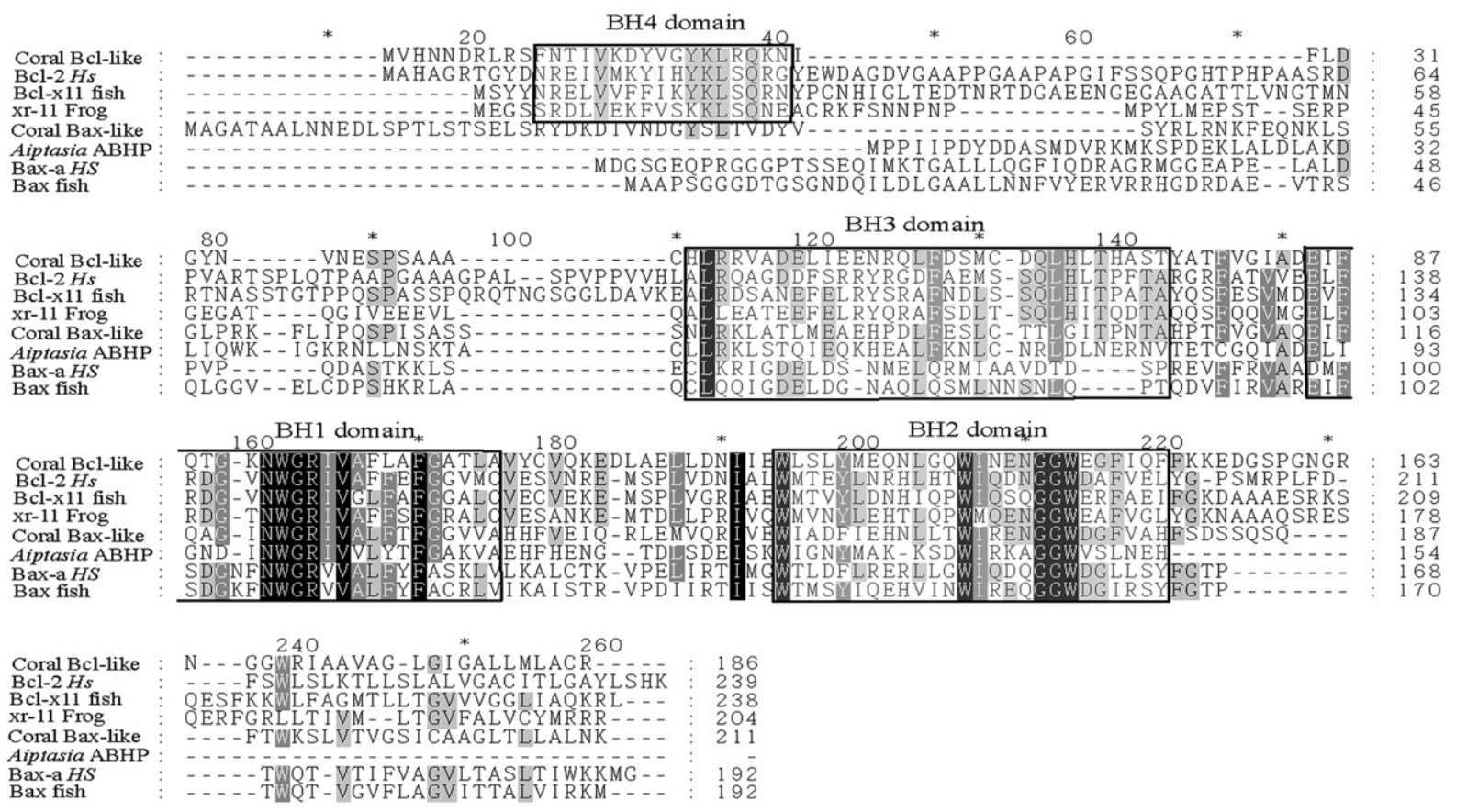

b

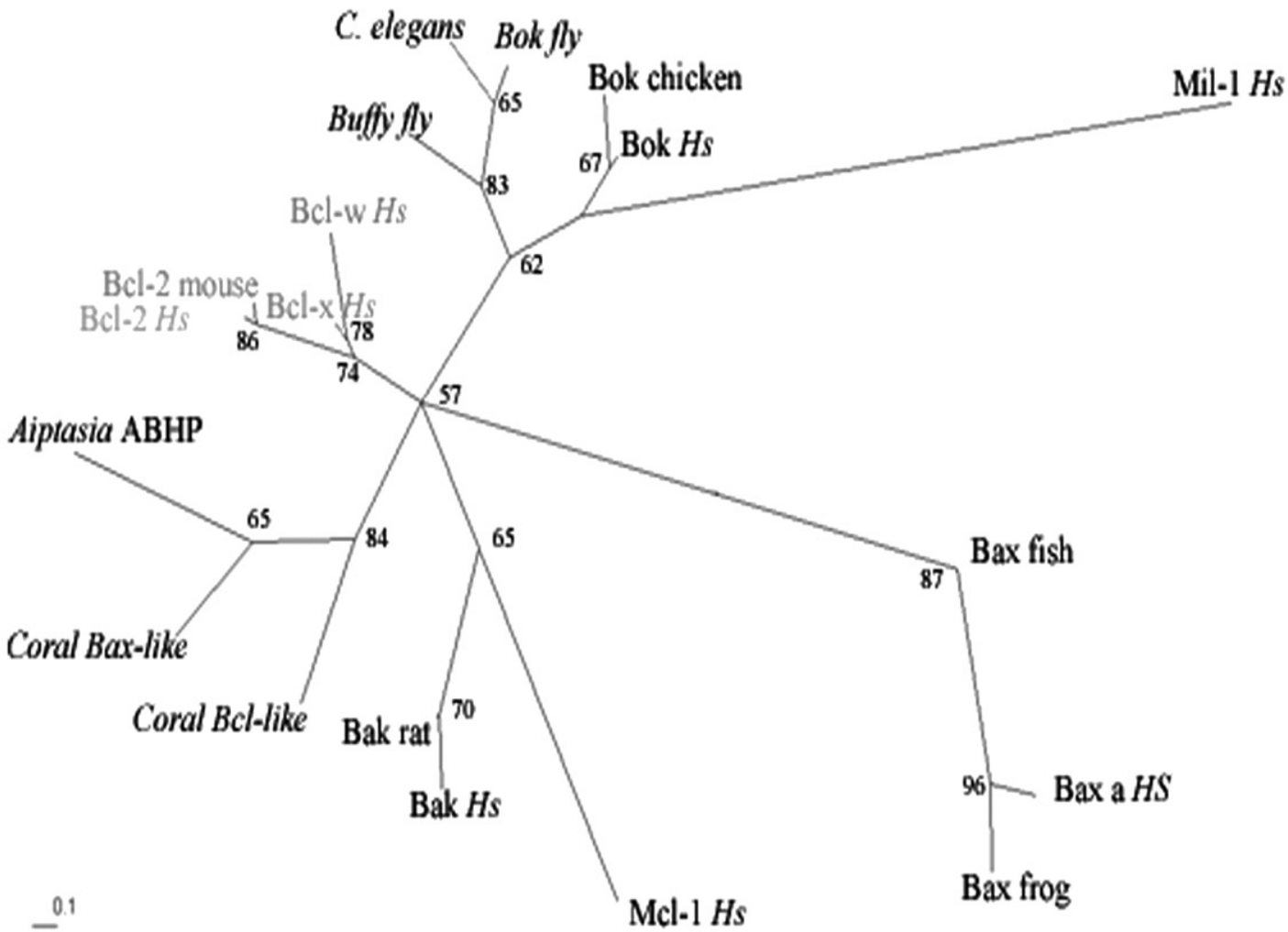

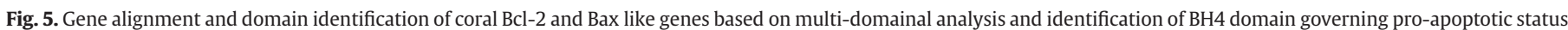

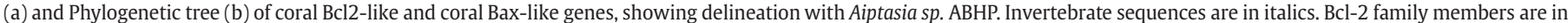
grey. Bootstrap values are indicated at branches.

measurements at two-week intervals through Dec 2005 indicates the rapid increase in thermal stress across the Capricorn and Bunker groups (Fig. 6). Significant temperature increases occurred during the one-week periods ending 16 Dec 2005 and 30 Dec 2005 for Heron Island (4 km-weekly satellite SST) (Fig. 6). The long-term temperature average (maximum monthly means (MMM) and the $4 \mathrm{~km}$ weeklymean $(\mathrm{WM})$ ) demonstrate that temperatures were above the usual weekly average for that time of year throughout the month of December and exceeded the average summertime maximum (MMM) (Fig. 7a). While the observed temperature anomaly was not as sustained as that used in the experimental treatments it provided a unique opportunity to determine if similar processes those under experimental conditions, would be observed in within an ecological setting. 

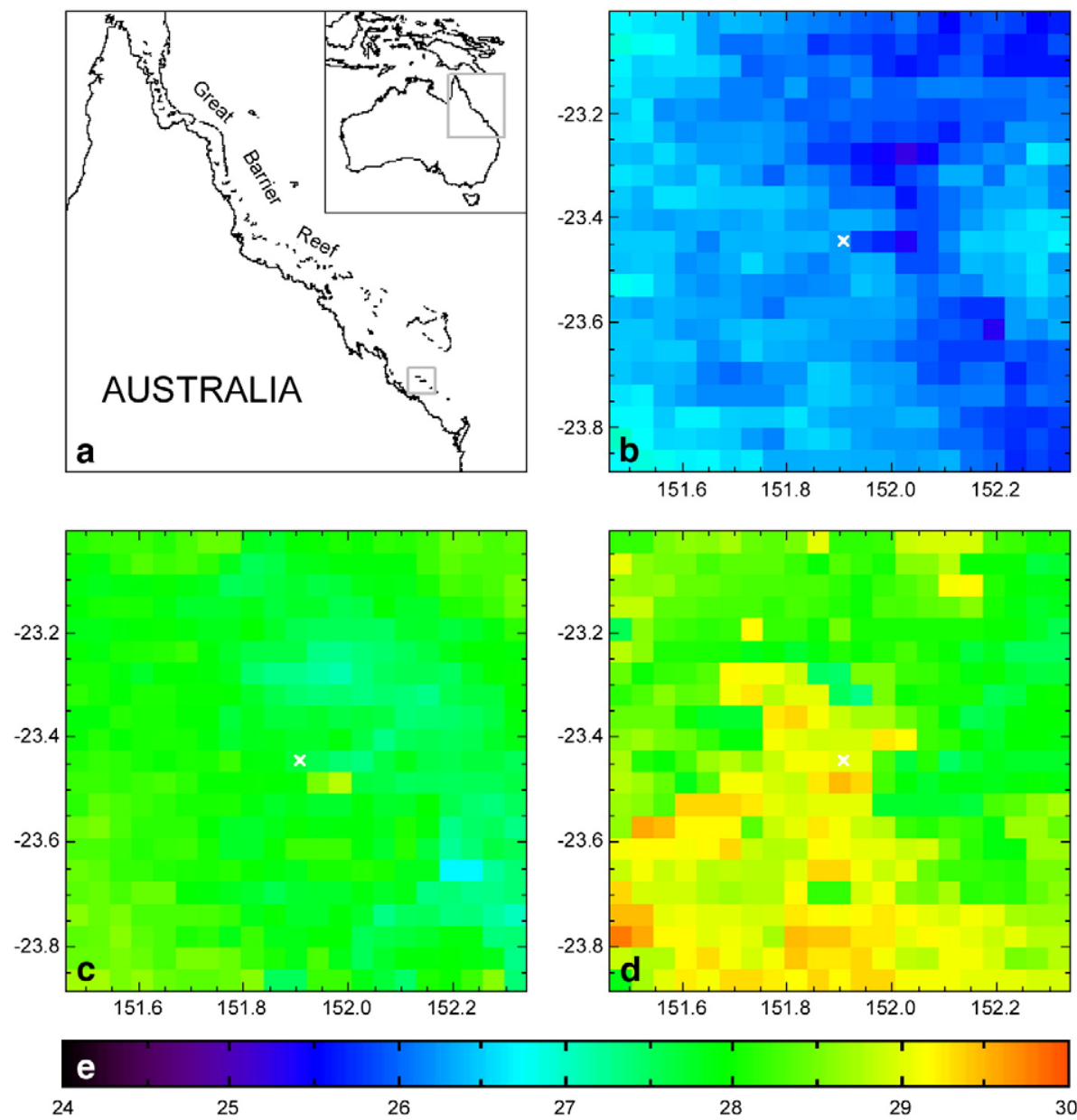

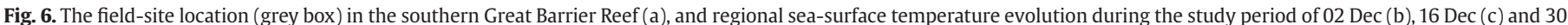
$\mathrm{Dec}(\mathrm{d}) 2005$. The location of Heron Island is indicated by symbol ' $\mathrm{x}$ '. Sea-surface changes are represented by the colour scale $\left({ }^{\circ} \mathrm{C}\right)(\mathrm{e})$.
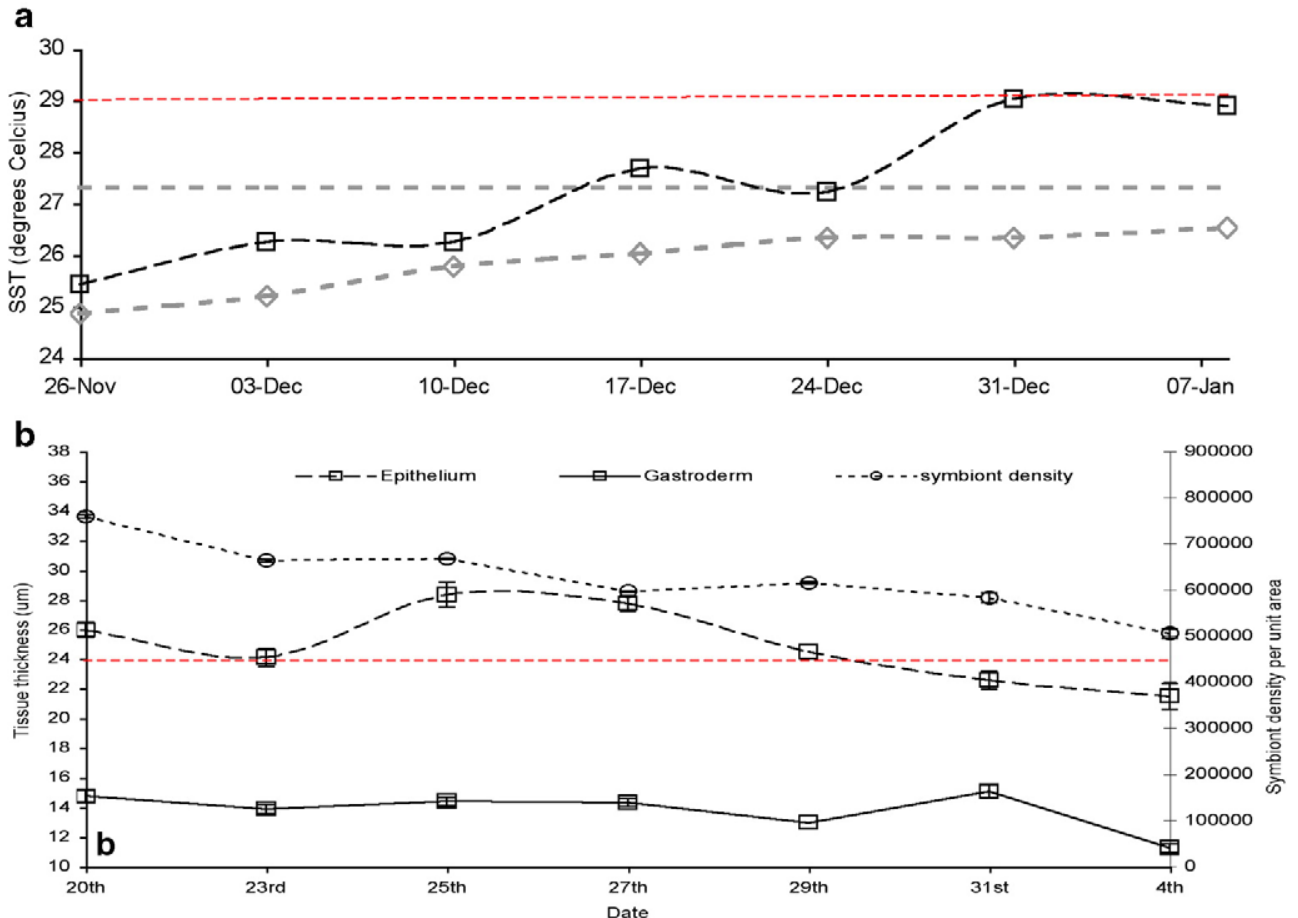

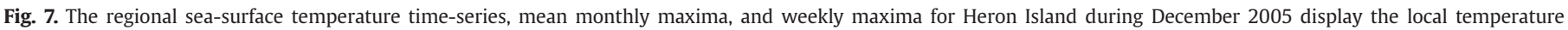

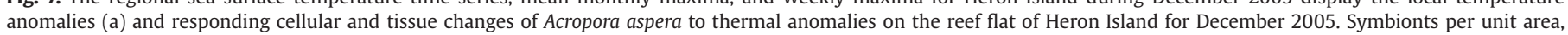
equates to symbionts per $\mathrm{cm}^{2}$ of coral tissue. Red dashed line indicates 29 degrees Celsius (a) and 24um tissue thickness (b). 
Haphazard sampling was only possible during the field bleaching, however it was determined that Symbiodinium densities had decreased by approximately $20 \%$ during the period of 20 th-29th December 2005 and 33\% by 4th January 2006, consistent with the period when the SST was greater than $1{ }^{\circ} \mathrm{C}$ above the MMM. While changes were smaller than those seen in the experiments, there was a decrease from the endosymbiont densities observed on the 20th December 2005. Unfortunately it was not possible to obtain field measurements of PSII dark adapted yield during this time. Host tissue and cellular changes were similar to those seen in the experiments, and tracked changes in sea temperature observed in the Capricorn bunker group of Islands (Fig. 7a) during the period 20th-29th December 2005 (Fig. 7a). Increases in seawater temperature corresponded to a reduction in epithelial tissue thickness, prior to bleaching associated reductions in Symbiodinium densities. This pattern of tissues changes within an ecological setting reflects that of the experimental trials (Fig. 7b). The changes seen in the field were however muted by comparison to the changes seen in the experiments, reflecting the milder time course of changes occurring in the field (Fig. 2 versus Fig. 7).

\section{Discussion}

Here we see that sub-cellular and cellular responses occur in the coral host at lower temperatures not previously considered detrimental. Coral host cellular responses occur at temperatures below $30{ }^{\circ} \mathrm{C}$, with early changes within the host tissues including apoptotic cell death in the gastrodermis and a reduction in the epithelial cell layer thickness. These cellular changes continue as thermal stress increases, with extensive cellular changes evident before the onset of symbiont loss or reduction in maximum photosynthetic yields of the dinoflagellate. This demonstrates that important changes to the host are induced during periods of extreme, but not bleaching level climate conditions. This has the potential to have implications to our understanding of coral cell stress biology and physiology that have previously been overlooked.

Gates et al. (1992) outlined 5 cellular mechanisms that may underpin the loss of symbionts from the coral host during coral bleaching events. Our study reveals that different cellular mechanisms are involved in the sequence of events associated with thermal stress within the host prior to and during the loss of symbionts. Apoptotic cell death and reduction of tissue layers occurred early in the stress response, whereas mass necrosis was is evidence for gross injury to the organism related to the breakdown of the symbiosis. The loss of dinoflagellates and/or their pigments from symbiosis during bleaching is a relatively late event in the cellular sequence of thermal stress by comparison to the mechanisms occurring within the host. The presence of putative pro- and anti-apoptotic genes also confirms that coral host cells have the potential to trigger host controlled cellular processes such as apoptosis and this represents the first time that both putative pro- and anti-apoptotic genes have been described from Cnidarians and shows similarity to that described across lower invertebrates (for reviews of identified lower invertebrate apoptotic genes see David et al., 2005 and Zmasek et al., 2007). Given that apoptosis probably incurs a cost to overall organism fitness, for example through the expression of new protein sets, sea surface temperatures below $30{ }^{\circ} \mathrm{C}$ may have major implications to holobiont physiology which have previously been overlooked. Sea surface temperatures of only $1{ }^{\circ} \mathrm{C}$ above long term summer maxima have been shown to cause coral bleaching (Lui et al., 2003; Gleeson and Strong, 1995). The impact of thermal stress on coral cell physiology maybe more complicated than those linked to observable mass bleaching events. As seen here sub-cellular and cellular responses in the host occur at lower temperatures, the role of these host thermal stress responses in potentially driving disease susceptibility or colony mortality in times of further stress needs to be investigated.
Our understanding of the long-term effects of these sub-cellular and cellular stressors in corals is extremely limited. For example, some coral species are suggested to exhibit lower capability for thermal adaptation and higher susceptibility to bleaching and disease, however there is little understanding of what is driving this at a physiological and cellular level. Understanding the thermal stress impacts to the host may help to understand if different mechanisms are driving long-term consequences to coral colonies. For example, the epithelial layer of corals is largely comprised of mucus producing cells, and mucus plays an important role in waste removal, antimicrobial defences and coral stasis (Wild et al., 2004; Brown and Bythell, 2005; Ritchie, 2006). It is estimated that the dominant reef building coral genus Acropora may exude up to 4.81 of mucus per square metre of reef per day, equating approximately 10$21 \mathrm{mmol}$ of particulate organic carbon (Wild et al., 2004). This release is thought to increase during periods of environmental stress and the impacts of pre-bleaching temperatures on the host cell biology may have significant impacts to the long-term energy reserves of the holobiont. Reduced epithelial thickness as seen in this study may have resulted from mucus release and depletion of the mucus reserves within the epithelial layer. This has the potential to contribute further demands to the symbiont (the primary source of energy) during the onset of bleaching temperature thermal stress and further impact the coral physiology, mucus production. Given that Acroporid corals are considered among the most susceptible to both bleaching (Marshall and Baird, 2000) and disease (Sutherland et al., 2004), the short and longterm impact of epithelial reductions and mucus loss during early environmental stressors needs to be determined especially considering the role of mucus in waste removal and energy reserves. Furthermore the 'pre-bleaching' temperatures and subsequent impacts to the host as shown in this study should also be included in models investigating links between thermal stress and later disease events.

\section{Conclusion}

In conclusion, Miller et al. (2007) have shown the coral host is much more complex than previously thought, having a compliment of molecular pathways through which the coral can illicit complex immune and stress responses. This study demonstrates that prebleaching thermal stressors are important to investigate and that the molecular, sub-cellular and cellular stress responses of the host, which have the potential to impact the holobiont physiology, need to be determined especially if we are to understand the role of environmental stressors in long-term outcomes such as disease. Understanding how stress affects both partners in the symbiosis and in combination (holobiont) is necessary if we are to understand the ecosystem changes that are already occurring in the environment in response to environmental stress. Given the early onset of sub-cellular and cellular responses as demonstrated within this study, it must be noted that impacts of environmental stress to coral colonies involve more than those occurring during observable "bleaching events". The role of these sub-cellular and cellular impacts in governing short and long-term survival of the individual coral colonies and consequently coral reefs must also be considered.

\section{Acknowledgments}

The authors would like to thank Dr Sophie Dove, Dr Oren Levy and Ms Rachael Middlebrook for assistance during sample collection at Heron Island Research Station. We also thank the staff of Heron Island Research Station and $\mathrm{Mr}$ David Harris for assistance with the experimental set up, design and sample collection. The authors also thank Ms Dorothea Burgess for conceptual and logistical support. We also thank the ARC Centre of Excellence for Coral Reef Studies (http:// www.coralcoe.org.au/) and The GEF Coral Reef Targeted Research Program (http://www.gefcoral.org) for financial support of this research project. The manuscript contents are solely the opinions of 
the authors and does not constitute a statement of policy, decision, or position on behalf of NOAA or the U. S. Government. [SS]

\section{References}

Ainsworth, T.D., Fine, M., Blackall, L.L., Hoegh-Guldberg, O., 2006. Fluorescence in situ hybridization and spectral imaging of coral-associated bacterial communities. Appl. Environ. Microbiol. 72 (4), 3016-3020.

Ainsworth, T.D., Kvennefors, E.C., Blackall, L.L., Fine, M., Hoegh-Guldberg, O., 2007. Disease and cell death in white syndrome of Acroporid corals on the Great Barrie Reef. Mar. Biol 151 (1), 19-29.

Ayres, P.G., 1984. The interaction between environmental stress, injury and biotic disease physiology. Ann. Rev. Phytopathol. 22, 53-75.

Ayres, M.P., Lombardero, M.J., 2000. Assessing the consequences of global change for forest disturbance from herbivores and pathogens. Sci. Total Environ. 262 (3), 263-286.

Boland, G.J., Melzer, M.S., Hopkin, A., Higgins, V., Nassuth, A., 2004. Climate change and plant diseases in Ontario. Can. J. Plant Pathol. 26, 335-350.

Brown, B.E., Bythell, J.C., 2005. Perspectives on mucus secretion in reef corals. MEPS 296 291-309.

Bruno, J.F., Selig, E.R., Casey, K.S., Page, C.A., Willis, B.L., Harvell, C.D., Sweatman, H., Melendy, A.M., 2007. Thermal stress and coral cover as drivers of coral disease outbreaks. PLoS Biol. 5 (6), 1120-1127.

Coles, S.L., Jokiel, P.L., 1977. Effects of temperature on photosynthesis and respiration in hermatypic corals. Mar. Biol. 43 (3), 209-216.

David, C.N., Schmidt, N., Schade, M., Pauly, B., Alexandrova, O., Bottger, A., 2005. Hydra and the evolution of apoptosis. Integr. Comp. Biol. 45 (4), 631-638.

Dove, S., 2004. Scleractinian corals with photoprotective host pigments are hypersensitive to thermal bleaching. MEPS 272, 99-116.

Dove, S., Ortiz, J.C., Enriquez, S., Fine, M., Fisher, P., Iglesias-Prieto, R., Thornhill, D. Hoegh-Guldberg, O., 2006. Response of holosymbiont pigments from the scleractinian coral Montipora monasteriata to short-term heat stress. Limnol. Oceanogr. 51 (2), 1149-1158.

Dunn, S., Phillips, W., Spatafora, J., Green, D., Weis, V., 2006. Highly Conserved Caspase and Bcl-2 Homologues from the Sea Anemone Aiptasia pallida: Lower Metazoans as Models for the Study of Apoptosis Evolution. J. Mol. Evol. 63 (1), 95-107.

Edmunds, P.J., Gates, R.D., 2003. Has coral bleaching delayed our understanding of fundamental aspects of coral-dinoflagellate symbioses? Bioscience 53 (10), 976-980

Elmore, S., 2007. Apoptosis: A review of programmed cell death. Toxicol. Pathol. 35 (4), 495-516.

Felsenstein, J., 1989. PHYLIP - Phylogeny Inference Package (Version 3.2). Cladistics 5 , 164-166.

Fitt, W.K., Brown, B.E., Warner, M.E., Dunne, R.P., 2001. Coral bleaching: interpretation of thermal tolerance limits and thermal threshold in tropical corals. Coral Reefs 20 $51-65$

Garrett, K.A., Dendy, S.P., Frank, E.E., Rouse, M.N., Travers, S.E., 2006. Climate Change Effects on Plant Disease: Genomes to Ecosystems. Ann. Rev. Phytopathol. 44 (1) 489-509.

Gates, R.D., Baghdasarian, G., Muscatine, L., 1992. Temperature stress causes host cell detachment in symbiotic cnidarians: Implications for coral bleaching. Biol. Bull. $182(3), 324-332$

Genty, B., Briantais, J.M., Baker, N.R., 1989. The relationship between the quantum yield of photosynthetic electron transport and quenching of chlorophyll fluorescence. Biochim. Biophys. Acta 990, 87-92.

Gleeson, M.W., Strong, A.E., 1995. Applying MCSST to coral reef bleaching. Adv. Space Res. 16 (10), 151-154.

Glynn, P.W., 1991. Coral reef bleaching in the 1980s and possible connections with globa warming. Trends Ecol. Evol. 6 (6), 175-179.

Glynn, P.W., D'Croz, L., 1990. Experimental evidence for high temperature stress as the cause of El Niño-coincident coral mortality. Coral Reefs 8 (4), 181-191.

Harvell, C.D., Mitchell, C.E., Ward, J.R., Altizer, S., Dobson, A.P., Ostfeld, R.S., Samuel, M.D. 2002. Climate warming and disease risks for terrestrial and marine biota. Science 296 (5576), 2158-2162.

Hoegh-Guldberg, O., 1999. Climate change, coral bleaching and the future of the world's coral reefs. Mar. Freshw. Res. 50, 839-866.

Hoegh-Guldberg, O., Fine, M., 2004. Low temperatures cause coral bleaching. Coral Reefs 23 (3), 444

Hoegh-Guldberg, O., Smith, G.J., 1989. The effect of sudden changes in temperature, light and salinity on the population density and export of zooxanthellae from the reef corals Stylophora pistillata Esper and Seriatopora hystrix Dana. JEMBE 129 (3), 279-303.

Hughes, T.P., Baird, A.H., Bellwood, D.R., Card, M., Connolly, S.R., Folke, C., Grosberg, R., Hoegh-Guldberg O. Jackson, J.B.C. Kleypas, J. Lough, J.M., Marshall, P., Nystrom, M. Palumbi, S.R., Pandolfi, J.M., Rosen, B., Roughgarden, J., 2003. Climate Change Human Impacts, and the Resilience of Coral Reefs. Science 301 (5635), 929-933.

Iglesias-Prieto, R., 1997. Temperature-dependent inactivation of photosystem II in symbiotic dinoflagellates, pp. 1313-1318

Jones, R., 2005. The ecotoxicological effects of Photosystem II herbicides on corals. Mar. Pollut. Bull. 51 (5-7), 495-506.

Jones, R.J., Hoegh-Guldberg, O., 1999. Effects of cyanide on coral photosynthesis: implications for identifying the cause of coral bleaching and for assessing the environmental effects of cyanide fishing. MEPS 177, 83-91.
Jones, R.J., Hoegh-Guldberg, O., Larkum, A.W.D., Schreiber, U., 1998. Temperatureinduced bleaching of corals begins with impairment of the $\mathrm{CO}_{2}$ fixation mechanism in zooxanthellae. Plant Cell Environ. 21, 1219-1230.

Jones, R.J., Kildea, T., Hoegh-Guldberg, O., 1999. PAM chlorophyll fluorometry: a new in situ technique for stress assessment in scleractinian corals, used to examine the effects of cyanide from cyanide fishing. Mar. Pollut. Bull. 38 (10), 864-874.

Jones, R.J., Ward, S., Amri, A.Y., Hoegh-Guldberg, O., 2000. Changes in quantum efficiency of Photosystem II of symbiotic dinoflagellates of corals after heat stress, and of bleached corals sampled after the 1998 Great Barrier reef mass bleaching event. Mar. Freshw. Res. 51, 63-71.

Kerswell, A.P., Jones, R.J., 2003. Effects of hypo-osmosis on the coral Stylophora pistillata: nature and cause of 'low-salinity bleaching'. MEPS 253, 145-154.

Kleppel, G.S., Dodge, R.E., Reese, C.J., 1989. Changes in Pigmentation Associated with the Bleaching of Stony Corals. Limnol. Oceanogr. 34 (7), 1331-1335.

Lanave, C., Santamaria, M., Saccone, C., 2004. Comparative genomics: the evolutionary history of the Bcl-2 family. Gene 333, 71-79.

Leggat, W., Whitney, S.M., Yellowlees, D., 2004. Is coral bleaching due to the instability of the zooxanthellae dark reactions? Symbiosis 37, 137-153.

Leggat, W., Ainsworth, T.D., Dove, S., Hoegh-Guldberg, O., 2006. Aerial exposure influences bleaching patterns. Coral Reefs 25, 452.

Leggat, W., Hoegh-Guldberg, O., Dove, S., Yellowlees, D., 2007a. Analysis of an EST library from the dinoflagellate (Symbiodinium sp.) symbiont of reef-building corals. J. Phycol. 43, 1010-1021.

Leggat, W., Ainsworth, T., Bythell, J., Dove, S., Gates, R., Hoegh-Guldberg, O., IglesiasPrieto, R., Yellowlees, D., 2007b. The hologenome theory disregards the coral holobiont. Nat. Rev. Micro. 5 (10). doi:10.1038/nrmicro1635C1.

Lesser, M.P., 1996. Elevated temperatures and ultraviolet radiation cause oxidative stress and inhibit photosynthesis in symbiotic dinoflagellates. Limnol. Oceanogr. 41 (2), 271-283.

Lesser, M.P., Farrell, J.H., 2004. Exposure to solar radiation increases damage to both host tissues and algal symbionts of corals during thermal stress. Coral Reefs 23 (3), 367-377.

Lesser, M.P., Stochaj, W.R., Tapley, D.W., Shick, J.M., 1990. Bleaching in coral reef anthozoans: effects of irradiance, ultraviolet radiation, and temperature on the activities of protective enzymes against oxygen radicals. Coral Reefs 8, 225-232.

Lesser, M.P. Bythell, J.C. Gates, R.D., Johnston, R.W. Hoegh-Guldberg, O., 2007. Are infectious diseases really killing corals? Alternative intrepetations of the experimental and ecological data. JEMBE 346 (1-2), 36-44.

Lui, G., Strong, A.E., Skirving, W.J., 2003. Remote sensing of sea surface temperatures during 2002 barrier reef coral bleaching. Transactions of the American Geophysical Union, vol. 84, pp. 137-141.

Marshall, P.A., Baird, A.H., 2000. Bleaching of corals on the Great Barrier Reef: differential susceptibilities among taxa. Coral Reefs 19 (2), 155-163.

Miller, D., Hemmrich, G., Ball, E., Hayward, D., Khalturin, K., Funayama, N., Agata, K., Bosch, T., 2007. The innate immune repertoire in Cnidaria - ancestral complexity and stochastic gene loss. Gen. Biol. 8 (4), R59.

Porter, J.W., Fitt, W.K., Spero, H.J., Rogers, C.S., White, M.W., 1989. Bleaching in Reef Corals: Physiological and Stable Isotopic Responses. PNAS 86 (23), 9342-9346.

Ritchie, K.B., 2006. Regulation of microbial populations by coral surface mucus and mucus-associated bacteria. MEPS 322, 1-14

Rosenberg, E., Koren, O., Reshef, L., Efrony, R., Zilber-Rosenberg, I., 2007. The role of microorganisms in coral health, disease and evolution. Nat. Rev. Micro. 5 (5), 355-362.

Spierings, D., McStay, G., Saleh, M., Bender, C., Chipuk, J., Maurer, U., Green, D.R., 2005. Connected to Death: The (Unexpurgated) Mitochondrial Pathway of Apoptosis. Science 310 (5745), 66-67.

Sutherland, K.P., Porter, J.W., Torres, C., 2004. Disease and immunity in Caribbean and Indo-Pacific zooxanthellate corals. MEPS 266 (273), 302

Szmant, A.M., Gassman, N.J., 1990. The effects of prolonged "bleaching" on the tissue biomass and reproduction of the reef coral Montastrea annularis. Coral Reefs 8 (4), 217-224.

Takahashi, S., Nakamura, T., Sakamizu, M., Woesik, R.V., Yamasaki, H., 2004. Repair Machinery of Symbiotic Photosynthesis as the Primary Target of Heat Stress for Reef-Building Corals. Plant Cell Physiol. 45 (2), 251-255.

Takahashi, S., Whitney, S., Itoh, S., Maruyama, T., Badger, M., 2008. Heat stress causes inhibition of the de novo synthesis of antenna proteins and photobleaching in cultured Symbiodinium. PNAS 105 (11), 4203-4208.

Tchernov, D., Gorbunov, M.Y., de Vargas, C., Narayan Yadav, S., Milligan, A.J., Haggblom, M., Falkowski, P.G., 2004. Membrane lipids of symbiotic algae are diagnostic of sensitivity to thermal bleaching in corals. PNAS 101 (37), 13531-13535.

Thompson, J.D., Higgins, D.G., Gibson, T.J., 1994. CLUSTAL W: improving the sensitivity of progressive multiple sequence alignment through sequence weighting, positionspecific gap penalties and weight matrix choice. Nucleic Acids Res. 22, 4673-4680.

Warner, M.E., Fitt, W.K., Schmidt, G.W., 1999. Damage to photosystem II in symbiotic dinoflagellates: a determinant of coral bleaching. PNAS 96, 8007-8012.

Wild, C., Huettel, M., Klueter, A., Kremb, S.G., Rasheed, M.Y.M., Jórgensen, B.B., 2004. Coral mucus functions as an energy carrier and particle trap in the reef ecosystem. Nature 428, 66-70.

Zmasek, C.M., Zhang, Q., Ye, Y., Godzik, A., 2007. Surprising complexity of the ancestral apoptosis network. Gen. Biol. 8 (10), R226. 